\title{
BORON CARBIDE BASED CERAMIC COMPOSITES HOT PRESSED WITH ALUMINIUM ADDITIVE
}

\author{
Pavol Švec ${ }^{1 *}$, Zuzana Gábrišovál, Alena Brusilová ${ }^{1}$, L’ubomír Čaplovič ${ }^{2}$ \\ ${ }^{1}$ Institute of Technologies and Materials, Faculty of Mechanical Engineering, Slovak University of Technology in Bratislava, Bratislava, Slovakia \\ ${ }^{2}$ Institute of Materials Science, Faculty of Materials Science and Technology in Trnava, Slovak University of Technology in Bratislava, Trnava, Slovakia
}

*Corresponding author: pavol.svec@ stuba.sk +421 257296 339, Institute of Technologies and Materials, Faculty of Mechanical Engineering, Slovak University of Technology in Bratislava, Námestie slobody 17, 81231 Bratislava, Slovakia

Received: 23.03 .2020

Accepted: 20.05.2020

\begin{abstract}
Ceramic composite materials consisting of $\mathrm{B}_{4} \mathrm{C}$ matrix and $\mathrm{Al}_{8} \mathrm{~B}_{4} \mathrm{C}_{7}$ secondary phase were prepared by in situ reactive sintering of the initial powder mixture $\mathrm{B}_{4} \mathrm{C}$ - $\mathrm{Al}$ with concentration from 5 to $25 \mathrm{wt} . \% \mathrm{Al}$ sintering additives. The composite samples were hot pressed at the temperature of $1850^{\circ} \mathrm{C}$, pressure of $35 \mathrm{MPa}$, for $15 \mathrm{~min}$ in a vacuum atmosphere. The portion of $\mathrm{Al}_{8} \mathrm{~B}_{4} \mathrm{C}_{7}$ secondary phase increased from 3.3 to $22.1 \mathrm{wt} \%$ when increasing the concentration of $\mathrm{Al}$ sintering additive from 5 to 25 wt.\% Al. Significant improving of densification and mechanical properties was measured at increasing of $\mathrm{Al}$ sintering additive concentration from 5 to 10 wt.\% Al. The highest average hardness of $28.74 \mathrm{GPa}$ was achieved when adding $15 \mathrm{wt} . \% \mathrm{Al}$ sintering additive. The fracture toughness increased with concentration of $\mathrm{Al}$ sintering additive in whole concentration range with the highest average value of $5.92 \mathrm{MPa} . \mathrm{m}^{1 / 2}$ at $25 \mathrm{wt} . \% \mathrm{Al}$ sintering additives.
\end{abstract}

Keywords: boron carbide, ceramic composite, secondary phase, hardness, fracture toughness

\section{INTRODUCTION}

Boron carbide $\left(\mathrm{B}_{4} \mathrm{C}\right)$ based ceramic materials have been intensively studied, because of their excellent properties [1-3]. Due to its prevailing covalent bonding the boron carbide based ceramic materials are extremely hard. The high hardness, above $30 \mathrm{GPa}$, places it on the third place between hardest materials after diamond and cubic boron nitride [4-6]. $\mathrm{B}_{4} \mathrm{C}$ is corrosion and wear resistant and ambient and elevated temperatures [7-8]. Boron carbide is characterized by high melting temperature of $2450{ }^{\circ} \mathrm{C}$, it has low density of $2.52{\mathrm{~g} . \mathrm{cm}^{-3}}^{-3}$, high Young's modulus of $460 \mathrm{GPa}$ and high cross-section for absorption of neutrons [4, 10-12]. Difficult sinterability of $\mathrm{B}_{4} \mathrm{C}$ is one of the main problems of reliable compacts preparations. Hinder sinterability causes closed rest porosity in the sintered compacts, which is irremovable [7, 9, 10 12]. This stems from small coefficients of self-diffusion in $\mathrm{B}_{4} \mathrm{C}$. Full density of $\mathrm{B}_{4} \mathrm{C}$ cannot be achieved at pressureless sintering without sintering additives. $\mathrm{B}_{4} \mathrm{C}$ compacts with near full density of 2.52 g. $\mathrm{cm}^{-3}$ can be prepared by hot pressing at temperatures above $2300{ }^{\circ} \mathrm{C}$. However, the sintering at temperatures above $2000{ }^{\circ} \mathrm{C}$ causes the particle coarsening in ceramic compacts $[5,13]$. Using fine powder, adding of sintering additives and application of pressure at sintering allows decreasing of sintering temperature [12, 14-19].

One of the major disadvantages of $\mathrm{B}_{4} \mathrm{C}$ is its low fracture toughness, which have to be improved for successful applications of boron carbide based ceramics [17, 20]. An increase of fracture toughness of samples can be solved through sintering of ceramic composite systems, which enables decreasing of sintering temperature too. Choosing of suitable composite systems permits creation of new phases in situ during sintering. Sintering additives in form of some elements (such as $\mathrm{Al}$, $\mathrm{Hf}, \mathrm{Ti}, \mathrm{B}, \mathrm{C}$ ), and compounds (such as $\mathrm{Al}_{2} \mathrm{O}_{3}, \mathrm{HfO}_{2}, \mathrm{TiO}_{2}, \mathrm{ZrO}_{2}, \mathrm{Si}_{3} \mathrm{~N}_{4}, \mathrm{TiC}$, $\mathrm{W}_{2} \mathrm{~B}_{5}$ ) are used at fabrication of in situ sintered $\mathrm{B}_{4} \mathrm{C}$ based ceramic composite materials $[4,14,15]$. They improve densification and influence the microstructure and mechanical properties of sintered compact because of creation of new secondary phases. Secondary phases are essential mainly for enhancing of fracture toughness, which is critical for boron carbide based ceramic materials, because it achieves values only from 2 to $3 \mathrm{MPa} \cdot \mathrm{m}^{1 / 2}$. The composite hardness can decrease, as phases with smaller hardness in comparison to $\mathrm{B}_{4} \mathrm{C}$ are created [15].

Sintering of $\mathrm{B}_{4} \mathrm{C}$ based ceramic composite with $\mathrm{Al}$ additive is interesting because of its low density $[14,20]$. It is possible to densify the system at pressureless sintering, hot pressing and plasma spark sintering. Porous $\mathrm{B}_{4} \mathrm{C}$ skeleton can be infiltrated with molten aluminium. $\mathrm{Al}$ sintering additive is used at pressureless sintering of $\mathrm{B}_{4} \mathrm{C}-\mathrm{Al}$ system. Achieved structure is similar to boron carbide with some changes in elementary lattice cell. Compacts with the density from 95 to 99 $\%$ are possible to prepare at sintering temperatures from 2100 to $2200{ }^{\circ} \mathrm{C}$. Hot pressing can be used for increasing of densification when the sintering temperature decreases to $1600{ }^{\circ} \mathrm{C}$. Final composite is very dependent on the composition of powder mixture, densification value and sintering temperature. Sintering pressure has a positive effect on density and mechanical properties. $\mathrm{Al}$ additive enables sintering with in situ reactions and creating of composite consisting of $\mathrm{B}_{4} \mathrm{C}$ matrix reinforced with $\mathrm{Al}_{8} \mathrm{~B}_{4} \mathrm{C}_{7}$ secondary phase. $\mathrm{Al}_{8} \mathrm{~B}_{4} \mathrm{C}_{7}$ secondary phase can function as sintering additive to improve the sintering property of $\mathrm{B}_{4} \mathrm{C}$ based ceramic which could result in higher relative density, lower shrinkage rate and better mechanical properties compared to that without $\mathrm{Al}_{8} \mathrm{~B}_{4} \mathrm{C}_{7}$ secondary phase. $\mathrm{Al}_{8} \mathrm{~B}_{4} \mathrm{C}_{7}$ secondary phase can be used as high temperature construction material since it possesses density of $2.69 \mathrm{~g} . \mathrm{cm}^{-3}$, which is close to density of $\mathrm{B}_{4} \mathrm{C}\left(2.52 \mathrm{~g} . \mathrm{cm}^{-3}\right)$ [19-21].

\section{USED MATERIALS AND EVALUATION METHODS}

Densities, microstructures and mechanical properties of $\mathrm{B}_{4} \mathrm{C}$ based ceramic composite materials were studied on compacts prepared using hot pressing process of the initial powder mixture composed of $\mathrm{B}_{4} \mathrm{C}$ powder with different concentration of $\mathrm{Al}$ sintering additive. The initial $\mathrm{B}_{4} \mathrm{C}-\mathrm{Al}$ powder mixture contained 5, 10, 15, 20 and 25 wt.\% Al sintering additive. Their homogenisation was accomplished using wet mixing in horizontal mill with Teflon container and $\mathrm{B}_{4} \mathrm{C}$ mill balls in isobutyl alcohol lubricant. The green samples were die pressed in simple tool with floating die of cylindrical shape with diameter of $8 \mathrm{~mm}$ at pressure of $140 \mathrm{MPa}$. All samples were consequently hot pressed in graphite die with floating matrix of cylindrical shape at the temperature of $1850{ }^{\circ} \mathrm{C}$, pressing time of $15 \mathrm{~min}$ and pressure of $35 \mathrm{MPa}$ in a vacuum atmosphere with final vacuum value about $10 \mathrm{~Pa}$.

The densities of hot pressed samples were measured using Archimedes method. The microstructures were studied with Axiovert 40 MAT microscope and JEOL JSM-IT300 scanning electron microscope. The phase analysis was done using $X$ ray diffraction method with Philips PW 1710 diffractometer. Volume portion of phases was estimates using image analysis with software of AxioVision, module Mutiphase. The hardness and fracture toughness of ceramic composite materials were measured using Vickers indenter Buehler IndentaMet 1100 with load of $49.03 \mathrm{~N}$ and indentation time of $10 \mathrm{~s}$.

\section{RESULTS AND DISCUSSION}

\section{Densification of $\mathrm{B}_{4} \mathrm{C}$-Al initial powder mixture}

The average densities of ceramic composites prepared by hot pressing of the initial powder mixture $\mathrm{B}_{4} \mathrm{C}$ with different concentration of $\mathrm{Al}$ are summarised in tab. 1. Their densities increased from 93.90 to $98.85 \%$ when increasing the $\mathrm{Al}$ sintering additive concentration from 5 to $10 \mathrm{wt} . \% \mathrm{Al}$. Small differences in the 
densities, in the interval from 98.85 to $98.89 \%$, were measured for samples with the initial concentration in the interval from 10 to $25 \mathrm{wt}$.\% Al. These differences were lower than scatter of measured values, but the highest average density of $98.89 \%$ was measured for sample with the initial concentration of 15 wt. \% Al.

Table 1 Effect of $\mathrm{Al}$ concentration on density and portion of phases in $\mathrm{B}_{4} \mathrm{C}-\mathrm{Al}_{8} \mathrm{~B}_{4} \mathrm{C}_{7}$ composite

\begin{tabular}{|c|c|c|c|}
\hline Al concentration (wt.\%) & Density (\%) & $\mathbf{B}_{4} \mathbf{C}$ portion (vol.\%) & $\mathbf{A l}_{\mathbf{8}} \mathbf{B}_{\mathbf{4}} \mathbf{C}_{\mathbf{7}}$ portion (vol.\%) \\
\hline 5 & 93.90 & 96.7 & 3.3 \\
\hline 10 & 98.85 & 94.8 & 5.2 \\
\hline 15 & 98.89 & 92.8 & 7.2 \\
\hline 20 & 98.74 & 86.3 & 13.7 \\
\hline 25 & 98.84 & 77.9 & 22.1 \\
\hline
\end{tabular}

\section{Microstructure of $\mathrm{B}_{4} \mathrm{C}-\mathrm{Al}_{8} \mathrm{~B}_{4} \mathrm{C}_{7}$ ceramic composite}

Microstructure of ceramic composite materials with the initial concentration of 5 and 10 wt.\% Al sintering additives are depicted in Figs. 1 and 2. The microstructures contain three phases with different colours. The microstructures consist of grey matrix of boron carbide $\left(\mathrm{B}_{4} \mathrm{C}\right)$ phase, light areas of aluminium boron carbide $\left(\mathrm{Al}_{8} \mathrm{~B}_{4} \mathrm{C}_{7}\right)$ phase and small portion of dark areas which represent rest porosity of samples. All samples had similar microstructure but with different portion of observed phases. The portion ratio of $\mathrm{Al}_{8} \mathrm{~B}_{4} \mathrm{C}_{7}$ secondary phase increased and the portion of rest porosity decreased with increased concentration of $\mathrm{Al}$ sintering additive in the initial powder mixture.

The identification of phase composition was realised by $\mathrm{X}$ ray diffraction analysis. All composites had similar XRD records with major portion of $\mathrm{B}_{4} \mathrm{C}$ phase which corresponds with grey areas in Fig. 1 and 2 and minor portion of $\mathrm{Al}_{8} \mathrm{~B}_{4} \mathrm{C}_{7}$ phase and it corresponds with light areas in Fig. 1 and 2. The formation of $\mathrm{Al}_{8} \mathrm{~B}_{4} \mathrm{C}_{7}$ phase was in good agreement with theoretical background.

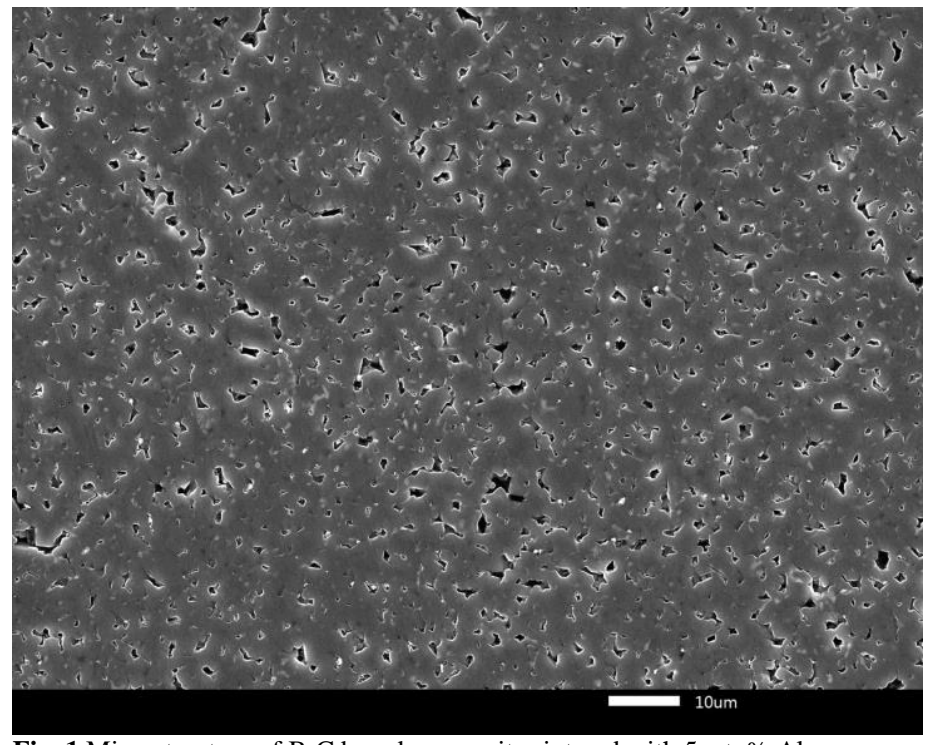

Fig. 1 Microstructure of $\mathrm{B}_{4} \mathrm{C}$ based composite sintered with 5 wt. \% $\mathrm{Al}$

The effect of $\mathrm{Al}$ concentration on the portion of observed phases measured using the image analysis is given in Table 1 . The portion of $\mathrm{Al}_{8} \mathrm{~B}_{4} \mathrm{C}_{7}$ phase was 3.3 vol.\% for sample in fig. 1 which was hot pressed from the initial powder mixture $\mathrm{B}_{4} \mathrm{C}$ with $5 \mathrm{wt} . \%$ of $\mathrm{Al}$ sintering additive.

The image analysis showed a positive effect of $\mathrm{Al}$ sintering additive on portion of $\mathrm{Al}_{8} \mathrm{~B}_{4} \mathrm{C}_{7}$ secondary phase in $\mathrm{B}_{4} \mathrm{C}-\mathrm{Al}_{8} \mathrm{~B}_{4} \mathrm{C}_{7}$ composite. The image analysis of composite microstructures showed that the portion of the $\mathrm{Al}_{8} \mathrm{~B}_{4} \mathrm{C}_{7}$ secondary phase increased from 3.3 to 22.1 vol. $\% \mathrm{Al}_{8} \mathrm{~B}_{4} \mathrm{C}_{7}$, but he portion of $\mathrm{B}_{4} \mathrm{C}$ matrix decreased from 96.7 to 77.9 vol. $\% \mathrm{~B}_{4} \mathrm{C}$ when increasing the concentration of $\mathrm{Al}$ sintering additives from 5 to $25 \mathrm{wt} . \%$ of $\mathrm{Al}$ sintering additive. The increase of $\mathrm{Al}_{8} \mathrm{~B}_{4} \mathrm{C}_{7}$ secondary phase portion with the increase of $\mathrm{Al}$ sintering additive concentration can be related to the larger extent of the in-situ reaction at higher concentration of Al.

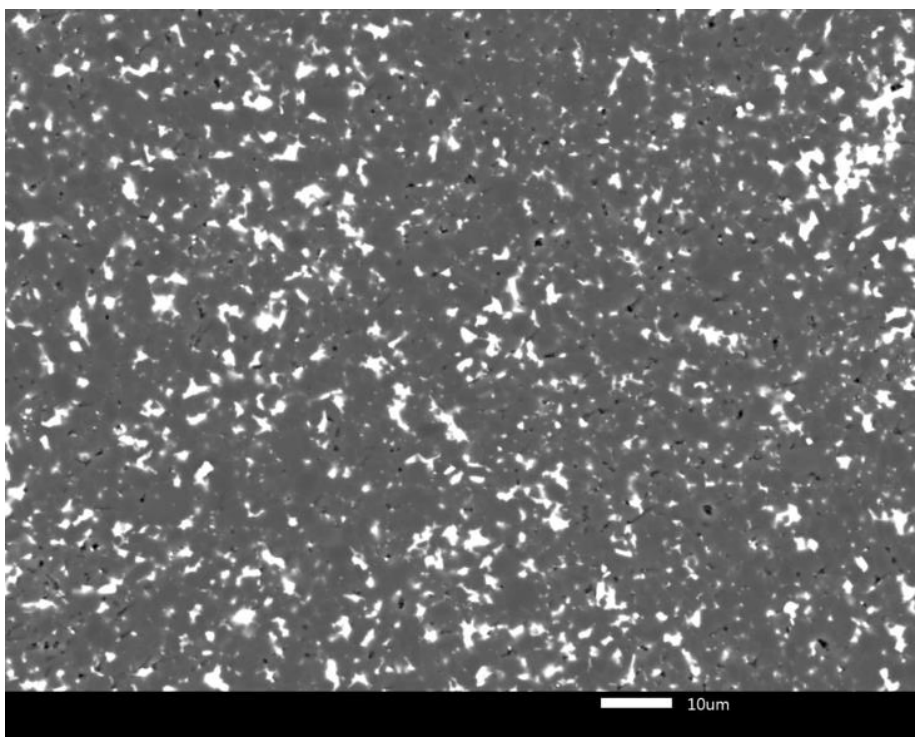

Fig. 2 Microstructure of $\mathrm{B}_{4} \mathrm{C}$ based composite sintered with 10 wt. \% $\mathrm{Al}$

\section{Mechanical properties of $\mathrm{B}_{4} \mathrm{C}-\mathrm{Al}_{8} \mathrm{~B}_{4} \mathrm{C}_{7}$ composite}

The effects of $\mathrm{Al}$ sintering additive concentration in the $\mathrm{B}_{4} \mathrm{C}-\mathrm{Al}$ initial powder mixture on the hardness and fracture toughness of $\mathrm{B}_{4} \mathrm{C}-\mathrm{Al}_{8} \mathrm{~B}_{4} \mathrm{C}_{7}$ ceramic composite materials are plotted in Figs. 3 and 4.

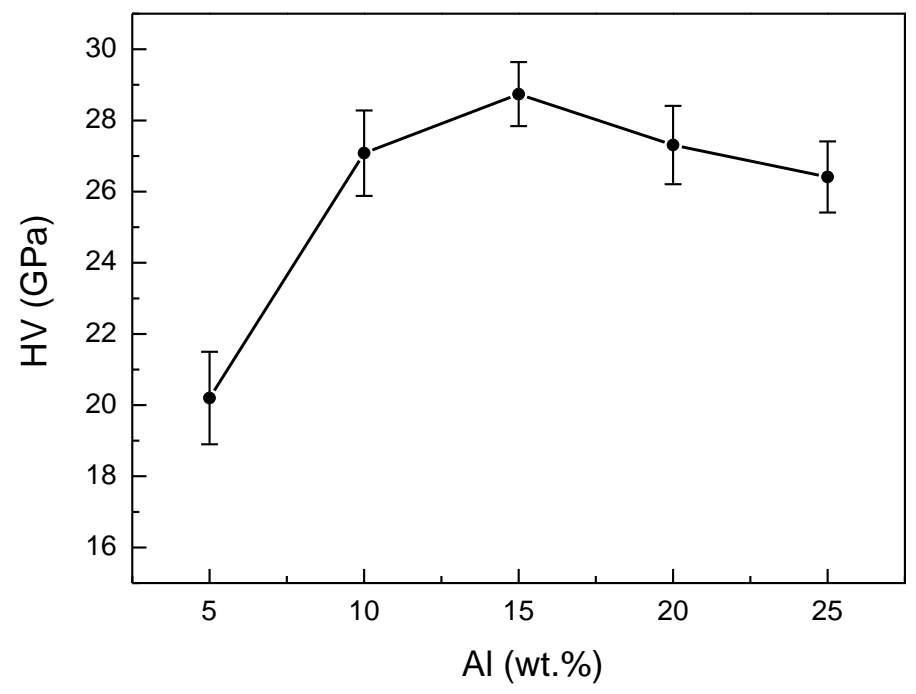

Fig. 3 Effect of $\mathrm{Al}$ on hardness of $\mathrm{B}_{4} \mathrm{C}$ based ceramic composite 


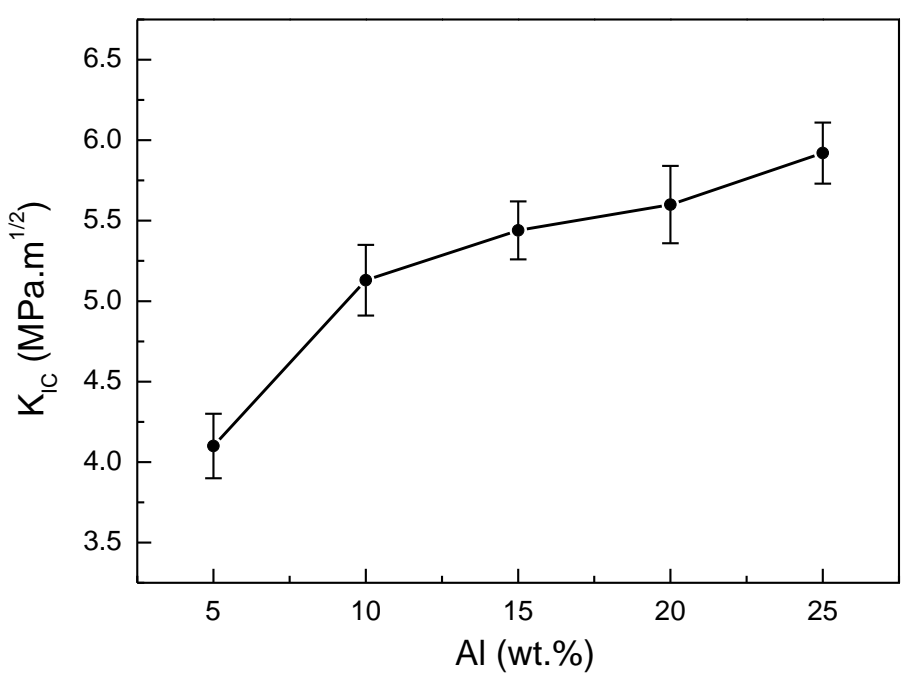

Fig. 4 Effect of $\mathrm{Al}$ on fracture toughness of $\mathrm{B}_{4} \mathrm{C}$ based ceramic composite

The effect of $\mathrm{Al}$ sintering additive on the hardness of $\mathrm{B}_{4} \mathrm{C}-\mathrm{Al}_{8} \mathrm{~B}_{4} \mathrm{C}_{7}$ ceramic composite presented in fig. 3 can be divided to two sections. Average hardness of $\mathrm{B}_{4} \mathrm{C}-\mathrm{Al}_{8} \mathrm{~B}_{4} \mathrm{C}_{7}$ ceramic composite increased from $20.20 \mathrm{GPa}$ to $28.74 \mathrm{GPa}$ in the concentration interval from 5 to $15 \mathrm{wt}$ \% $\mathrm{Al}$ sintering additive because of better densification of composite and larger extent of in situ reaction with increased concentration of Al. Average hardness of $\mathrm{B}_{4} \mathrm{C}-\mathrm{Al}_{8} \mathrm{~B}_{4} \mathrm{C}_{7}$ ceramic composite slightly decreased from $28.74 \mathrm{GPa}$ to $26.41 \mathrm{GPa}$ in the concentration interval from 15 to $25 \mathrm{wt}$. \% Al because of creation of large portion of secondary phase $\mathrm{Al}_{8} \mathrm{~B}_{4} \mathrm{C}_{7}$ with lower hardness compared to $\mathrm{B}_{4} \mathrm{C}$ matrix. The highest hardness of 28.74 GPa was achieved when adding 15 wt. $\% \mathrm{Al}$ sintering additive.

Addition of $\mathrm{Al}$ into $\mathrm{B}_{4} \mathrm{C}$ powder had the positive effect on the increase of fracture toughness in whole studied $\mathrm{Al}$ concentration range (see fig. 4). Average fracture toughness of $\mathrm{B}_{4} \mathrm{C}-\mathrm{Al}_{8} \mathrm{~B}_{4} \mathrm{C}_{7}$ composite increased from 4.10 to $5.92 \mathrm{MPa} \mathrm{m}^{1 / 2}$ with the increase of $\mathrm{Al}$ sintering additive concentration from 5 to $25 \mathrm{wt} . \% \mathrm{Al}$. The highest average fracture toughness of $5.92 \mathrm{MPa} \cdot \mathrm{m}^{1 / 2}$ was measured at composite with the highest concentration of $25 \mathrm{wt} . \% \mathrm{Al}$ sintering additives. The fracture toughness increased by $44 \%$ at the composite sintered with the highest concentration of sintering additive $(25 \mathrm{wt} . \% \mathrm{Al})$ compared to the composite with the lowest concentration of sintering additive ( $5 \mathrm{wt} \% \mathrm{Al}$ ). This effect can be explained by both toughening effect of $\mathrm{Al}_{8} \mathrm{~B}_{4} \mathrm{C}_{7}$ secondary phase and higher fracture toughness of $\mathrm{Al}_{8} \mathrm{~B}_{4} \mathrm{C}_{7}$ compared to $\mathrm{B}_{4} \mathrm{C}$ matrix.

\section{CONCLUSIONS}

Ceramic composite material consisting of boron carbide $\mathrm{B}_{4} \mathrm{C}$ matrix and aluminium boron carbide $\mathrm{Al}_{8} \mathrm{~B}_{4} \mathrm{C}_{7}$ secondary phase was prepared by hot pressing of the initial powder mixture $\mathrm{B}_{4} \mathrm{C}$-Al with concentration from 5 to $25 \mathrm{wt} \% \mathrm{Al}$. The composite samples were hot pressed at the temperature of $1850{ }^{\circ} \mathrm{C}$, pressure of $35 \mathrm{MPa}$, during hot pressing time of $15 \mathrm{~min}$ in vacuum atmosphere about 10 Pa.

Significant improving of average density of $\mathrm{B}_{4} \mathrm{C}$ based ceramic composite material from 93.90 to $98.85 \%$. was reached at increasing of $\mathrm{Al}$ sintering additive concentration from 5 to $10 \mathrm{wt} . \% \mathrm{Al}$. The highest average density of $98.89 \%$ was measured for composite with the initial concentration of 15 wt. \% Al sintering additive.

The portion of the $\mathrm{Al}_{8} \mathrm{~B}_{4} \mathrm{C}_{7}$ secondary phase increased from 3.3 to 22.1 vol.\% $\mathrm{Al}_{8} \mathrm{~B}_{4} \mathrm{C}_{7}$ when increasing the concentration of $\mathrm{Al}$ sintering additives in the initial $\mathrm{B}_{4} \mathrm{C}$ - $\mathrm{Al}$ powder mixture from 5 to $25 \mathrm{wt}$ \% of $\mathrm{Al}$ sintering additive.

The hardness of $\mathrm{B}_{4} \mathrm{C}-\mathrm{Al}_{8} \mathrm{~B}_{4} \mathrm{C}_{7}$ ceramic composite increased from $20.20 \mathrm{GPa}$ to $28.74 \mathrm{GPa}$ in the concentration interval from 5 to $15 \mathrm{wt}$. \% $\mathrm{Al}$ sintering additive because of better densification of composite and larger extent of in situ reaction with increased concentration of $\mathrm{Al}$ sintering additive.

Addition of $\mathrm{Al}$ into $\mathrm{B}_{4} \mathrm{C}$ powder had the positive effect on the increase of fracture toughness in whole studied $\mathrm{Al}$ concentration range. Average fracture toughness increased from 4.10 to $5.92 \mathrm{MPa} \cdot \mathrm{m}^{1 / 2}$ in $\mathrm{B}_{4} \mathrm{C}-\mathrm{Al}_{8} \mathrm{~B}_{4} \mathrm{C}_{7}$ composite with increase of concentration of $\mathrm{Al}$ sintering additive from 5 to $25 \mathrm{wt} . \% \mathrm{Al}$.
Acknowledgments: This work was supported by the Scientific Grant Agency of the Ministry of Education, Science, Research and Sport of the Slovak Republic under the VEGA 1/0298/18 contract. The work was supported by UVP STU Bratislava the ITMS 26240220084 project.

\section{REFERENCES}

1. Y. Gao et al.: Materials and Design, 92, 2016, 814-822. https://doi.org/10.1016/10.1016/j.matdes.2015.12.123

2. X. Zhang et al.: Ceramics International, 44(9), 2018, 10766-10772. https://doi.org/10.1016/j.ceramint.2018.03.114

3. L. Roumiguier, A. Jankowiak, N. Pradeilles, G. Antou, A. Maitre: Ceramics International, 45(8), 2019, 9912-9918.

https://doi.org/10.1016/j.ceramint.2019.02.033

4. D. Wang, S. Ran, L. Shen, H. Sun, Q. Huang: Journal of the European Ceramic Society, 35(3), 2015, 1107-1112,

https://doi.org/10.1016/j.jeurceramsoc.2014.10.018

5. H. Wie et al.: Ceramics International, 45(12), 2019, 14749-14755. https://doi.org/10.1016/j.ceramint.2019.04.201

6. P. Hvizdoš, A. Vencl: Ceramic Matrix Composites With Carbon Nanophases: Development, Structure, Mechanical and Tribological Properties and Electrical Conductivity, In book: Reference Module in Materials Science and Materials Engineering, first ed., Elsevier, Amsterdam, 2021, 1-18.

https://doi.org/10.1016/B978-0-12-803581-8.11858-2

7. B.M. Moshtaghioun, F.L. Cumbrera, A.L. Ortiz, M. Castillo-Rodríguez, D. Gómez-García: Journal of the European Ceramic Society, 34(3), 2014, 841-848. https://doi.org/10.1016/j.jeurceramsoc.2013.10.006

8. R.M. White, E.C. Dickey: Journal of the European Ceramic Society, 34(9), 2014, 2043-2050. https://doi.org/10.1016/j.jeurceramsoc.2013.08.012

9. D. Wang, H. Sun, Q. Deng, Z. Ding, S. Ran, Q. Huang: Ceramics International, 40(9), 2014, 15341-15344.

https://doi.org/10.1016/j.ceramint.2014.06.103

10. M.S. Heifari, H.R. Baharvandi: International Journal of Refractory Metals and Hard Materials, 51, 2015, 224-232.

https://doi.org/10.1016/j.ijrmhm.2015.04.003

11. R. Lu, S. Chandrasekaran, W.L. Du Frane, R.L. Landingham, M.A. Worsley, J.D. Kuntz: Materials and Design, 148, 2018, 8-16.

https://doi.org/10.1016/10.1016/j.matdes.2018.03.026

12. X. Li et al.: Ceramics International, 40(3), 2014, 4359-4366.

https://doi.org/10.1016/j.ceramint.2013.08.106

13. B.M. Moshtaghioun, M.A. Laguna-Bercero, D. Gomez-García, J.I. Pena: Journal of Alloys and Compounds, 795, 2019, 408-415. https://doi.org/10.1016/j.jallcom.2019.05.037

14. H. Latifi, A. Moradkhani, H. Baharvandi, J. Martikainen: Materials and Design, 62, 2014, 392-400. https://doi.org/10.1016/10.1016/j.matdes.2014.05.039 15. S. Faila, C. Melandri, L. Zoli, G. Zucca, D. Sciti: Journal of the European $\begin{array}{llll}\text { Ceramic Society, 38(9), 2018, 3089-3095. } & \end{array}$ https://doi.org/10.1016/j.jeurceramsoc.2018.02.041

16. X. Zhang et al.: Ceramics International, 43(8), 2017, 6345-6352, https://doi.org/10.1016/j.ceramint.2017.02.043

17. Q. Wen, Y. Tan, Z. Zhong, H. Zhang, X. Zhou: Materials Science and Engineering A, 701, 2017, 338-343. https://doi.org/10.1016/j.msea.2017.06.100

18. X. Zhang et al.: Ceramics International, 44(2), 2018, 2615-2619. https://doi.org/10.1016/j.ceramint.2017.10.230

19. J. Hu, F. Zhang, W. Wang, Z. Fu, J. Zhang: Journal of the European Ceramic Society, 39(9), 2019, 2874-2881.

https://doi.org/10.1016/j.jeurceramsoc.2019.03.028

20. K. Sairam et al.: Journal of the American Ceramic Society, 101, 2018, 25162526. https://doi.org/10.1111/jace. 15376

21. W. Ji, R.I. Todd, W. Wang, H. Wang, J. Zhang, Z. Fu: Journal of the European Ceramic Society, 36(10), 2016, 2419-2426.

https://doi.org/10.1016/j.jeurceramsoc.2016.03.028 